\title{
PERENGKAHAN KATALITIK MINYAK JELANTAH MENGGUNAKAN KATALIS Co- CARBON YAND DIHASILKAN DENGAN METODE ION EXCHANGE
}

\author{
NM Yuhermita ${ }^{1}, \mathrm{~N} \mathrm{Nazarudin}^{1,2,3^{*}}$ O Alfernando, ${ }^{2,3}$, IG Prabasari ${ }^{2,3}, \mathrm{M} \mathrm{Haviz}^{4}$, \\ ${ }^{1}$ Program Studi Teknik Kimia, Fakultas Teknik, Universitas Jambi \\ ${ }^{2}$ Program Studi Pendidikan Kimia, FKIP, Universitas Jambi \\ ${ }^{3}$ Pusat Studi Energi dan Nano Material, LPPM, Universitas Jambi \\ ${ }^{4}$ Program Studi Teknik Kimia, Fakultas Teknik, Universitas Lampung \\ Email :nazarudin@unja.ac.id
}

\section{Info Artikel}

Diterima: 02 Desember 2020

Disetujui: 26 Januari 2021

Dipublikasikan: 13 Maret 2021

\begin{abstract}
Abstrak
Penggunaan bahan bakar yang terus meningkat mengakibatkan cadangan minyak bumi mengalami penurunan. Bahan bakar minyak (BBM) yang berasal dari fosil tidak dapat diperbaharui. Biofuel adalah salah satu sumber energi alternatif. Pembuatan Biofuel dapat dilakukan dengan perengkahan termal dan perengkahan katalitik minyak goreng bekas. Minyak goreng bekas dapat menjadi biofuel dengan proses perengkahan katalitik menggunakan katalis Co-Arang. Penelitian ini meliputi preparasi katalis kobalt-arang aktif dengan metode ion exchange, Karakterisasi katalis, dan perengkahan katalitik minyak jelantah. Konsentrasi larutan logam yaitu $1 \%, 2 \%$, dan $3 \%$, dengan variasi temperatur perengkahan yaitu $450^{\circ} \mathrm{C}, 500^{\circ} \mathrm{C}, 550^{\circ} \mathrm{C}$. Karakterisasi dengan XRD menunjukkan struktur atom karbon berbentuk struktur amorf. Hasil karakterisasi dengan SEM-EDX didapatkan hasil logam kobalt yang teremban yaitu sebesar 0,86\%, 1,99\% dan $0,11 \%$. Konversi rata-rata (\%) CHP perengkahan minyak jelantah pada Konsentrasi katalis $1 \%, 2 \%$ dan 3\% adalah $31,83 \%, 8,51 \%$ dan $11,43 \%$. Produk perengkahan maksimum di dapatkan pada temperatur $450^{\circ} \mathrm{C}$ dengan konsentrasi Co-Arang $1 \%$ yaitu 47,55\%. Energi aktivasi perengkahan yaitu -40,64 kJ, 71,03 $\mathrm{kJ}$ dan $29,98 \mathrm{~kJ}$.
\end{abstract}

Kata kunci: perengkahan, minyak jelantah, katalis, Co-Arang, biofuel, kobalt

\begin{abstract}
:
The increasing of fuel oil (BBM) cause the reduction of fossil fuel. Fuel oil from fossil is non-renewable, so a biofuel become one of the alternative energy source. Used cooking oil can be converted into biofuel through a catalytic process using a catalyst Co-Carbon. This study included preparation of cobalt-activated carbon catalyst by ion exchange method, catalyst characterization, and catalytic cracking of used cooking oil. Metal concentration was varied at $1 \%, 2 \%$ and $3 \%$, with a variation of reaction temperature $450^{\circ} \mathrm{C}, 500^{\circ} \mathrm{C}, 550^{\circ} \mathrm{C}$. Catalysts were characterized by SEM-EDX and XRD. XRD patterns show amorphous carbon atomic structure. SEM-EDX characterization showed that $0,86 \%, 1,99 \%$ and $0.11 \%$ was impregnated into carbon pore. Average conversion $(\%)$ of catalytic cracking product in catalyst concentrations of $1 \%, 2 \%$ and $3 \%$ were $31,83 \%$, $8.51 \%$ and $11.43 \%$. Maximum product yield achieved at a temperature $450^{\circ} \mathrm{C}$ with Co-carbon concentration $1 \%$ was $47,55 \%$. The activation energy of cracking was $-40,64 \mathrm{~kJ}, 71.03 \mathrm{~kJ}$ and $29.98 \mathrm{~kJ}$.
\end{abstract}

Keywords: cracking, waste cooking oil, catalyst, Co-carbon, biofuel, Cobalt 


\section{Pendahuluan}

Penggunaan bahan bakar semakin meningkat setiap tahunnya, tanpa disertai upaya penyediaan bahan bakar alternatif. Bahan bakar yang digunakan sekarang berasal dari minyak mentah yang diambil dari perut bumi. Minyak bumi merupakan sumber energi primer yang berasal dari fosil dan tidak dapat diperbaharui serta ketersediaannya terbatas. Diperkiraan untuk beberapa tahun kedepan masyarakat akan kekurangan bahan bakar (Saputra and Ida, 2014). Pengembangan sumber energi alternatif perlu mendapat perhatian serius untuk mengantisipasi meningkatnya konsumsi energi, sementara cadangan bahan bakar fosil di alam terus menipis. Keterbatasan sumber daya dan penurunan cadangan bahan bakar fosil berpengaruh terhadap laju pertumbuhan ekonomi. Sejalan dengan pertumbuhan ekonomi maka kebutuhan energi pun meningkat. Oleh karena itu, diperlukan bahan bakar alternatif berbasis bahan terbarukan untuk mensubtitusi kebutuhan bahan bakar.

Salah satu upaya pemanfaaan energi alternatif adalah bahan bakar nabati (BBN). Di Indonesia tersedia beberapa bahan baku bioenergi, diantaranya singkong, kelapa sawit, dan jarak pagar. Selain bahan baku tersebut, terdapat pula bahan baku dari limbah yang dapat dimanfaatkan sebagai sumber energi alternatif yaitu minyak jelantah (Saputra and Ida, 2014). Minyak jelantah merupakan minyak bekas penggorengan yang telah digunakan dua kali atau lebih. Upaya pemanfaatan minyak jelantah perlu dilakukan agar minyak jelantah tidak terbuang dan menyebabkan pencemaran lingkungan. Pemanfaatan minyak jelantah merupakan alternatif terbaik untuk menghasilkan energi terbarukan. Minyak jelantah merupakan minyak goreng bekas yang telah rusak akibat proses oksidasi, polimerisasi, dan hidrolisis. Senyawa yang terbentuk akibat proses tersebut yaitu Asam lemak bebas yang dihasilkan dari penguraian trigliserida. Asam lemak bebas dengan rantai hidrokarbon panjang dapat dijadikan hidrokarbon yang lebih pendek melalui pemutusan rantai kabron asam lemak.

Perengkahan katalitik merupakan suatu cara untuk memecah hidrokarbon kompleks menjadi molekul yang lebih sederhana dengan bantuan katalis sehingga dapat meningkatkan kualitas dan kuantitas produk dan juga dapat menurunkan jumlah residu yang dihasilkan. Katalis yang digunakan pada perengkahan katalitik yaitu katalis logam pengemban. Logam-logam yang sering digunakan sebagai katalis adalah jenis logam transisi orbital d. Kekurangan katalis logam yaitu dapat terjadi penggumpalan komponen aktif logam ketika proses katalitik berlangsung, akibatnya umur katalis lebih pendek. Untuk mengatasi penggumpalan pada logam dan menambah umur katalis, katalis logam dapat diembankan pada bahan pendukung seperti silika-alumina, alumina atau arang aktif (Trisunaryanti et al dalam Shofa, 2016). Arang aktif dapat digunakan sebagai pengemban katalis karena arang aktif inert dan stabil dalam suasana asam maupun basa. Pada penelitian ini digunakan logam kobalt (Co) sebagai situs aktif katalis yang diembankan pada arang aktif dan digunakan pada suhu tinggi. Pengembanan logam dilakukan dengan metode pertukaran ion. Katalis Co-arang aktif dibuat dengan larutan ion logam yang dimasukkan kedalam arang aktif. Logam Kobalt digunakan sebagai katalis pada proses adsorpsi Ammonia dan Piridin, Konversi etanol dengan metode steam reforming, dan Sintesis Fischer Tropsch.

Penelitian yang telah dilakukan Riko (2013) membuktikan bahwa pengembanan logam meningkatkan selektivitas katalis terhadap biofuel yang dihasilkan. Semakin tinggi kadar logam pada katalis, semakin tinggi pula biofuel yang didapat. Menurut penelitian yang dilakukan Bachtas and Ida ( 2015), jumlah katalis pada perengkahan minyak jelantah sangat berpengaruh terhadap yield biofuel yang dihasilkan. Peningkatan jumlah katalis yang digunakan dapat meningkatkan perolehan produk dan \%yield juga semakin besar. Hal ini disebabkan dengan meningkatnya katalis yang digunakan pada perengkahan maka sisi aktif katalis meningkat dan energi aktivasi pada proses perengkahan katalitik menurun. Berdasarkan uraian tersebut, perengkahan katalitik minyak jelantah dapat dilakukan dengan beberapa variasi suhu dan menggunakan katalis yang dimodifikasi dengan pengembanan logam. Metode pengembanan logam yang dilakukan yaitu metode ion exchange. Maka dari itu, judul yang diambil dalam penelitian ini adalah "Perengkahan Minyak Jelantah Menggunakan Katalis Co-Arang dengan Metode Ion Exchange" 


\section{Metode Penelitian}

\section{Metode Pembuatan Katalis}

Persiapan katalis adalah langkah yang paling penting dalam pembuatan katalis. Ini karena tahap persiapan katalis hampir kompleks dan mengandung banyak rincian yang harus diketahui dan jelas untuk pembuatan katalis. Tujuan utama dari proses pembuatan katalis adalah untuk mendapatkan katalis dengan spesifikasi khusus untuk mencapai reaksi katalitik tertentu yang mengarah ke produktivitas industri atau lingkungan yang lebih tinggi melalui selektivitas dan aktivitas katalis yang tinggi. Proses pembuatan katalis juga mengandung parameter yang sangat penting yang pada dasarnya mengendalikan berbagai sifat katalis seperti prekursor, komposisi, pencampuran dan sebagainya (Deraz, 2018).

Metode yang paling umum yang digunakan untuk persiapan katalis adalah presipitasi atau kopresipitasi, impregnasi, sol-gel, pertukaran ion, adsorpsi, dan metode deposisi-presipitasi. Selain itu, ada metode baru yang digunakan untuk persiapan persiapan katalis seperti metode plasma, mikro emulsi, metode pembakaran dan elektro-spinning. Pada penelitian ini akan dibahas mengenai metode impregnasi dan ion exchange.

\section{Metode Impregnasi}

Impregnasi didefinisikan sebagai salah satu metode dalam preparasi katalis yang paling sederhana dan langsung. Metode impregnasi dilakukan dengan cara mengadsorpsikan komponen aktif logam dalam larutan kepada padatan pengemban. Tujuan dari impregnasi adalah untuk memenuhi pori pengemban dengan larutan garam logam dengan konsentrasi tertentu. Contoh katalis yang dibuat dengan metode pengisian pori adalah $\mathrm{Ni}$ atau Co pada $\mathrm{Al}_{2} \mathrm{O}_{3}-\mathrm{MoO}_{3}, \mathrm{MoO}_{3}$ pada alumina silikat termasuk zeolit, $\mathrm{Ni}$ atau Ag pada alumina, logam mulia pada karbon aktif, dll.

\section{Metode Pertukaran Ion (Ion Exchange)}

Metode pertukaran ion di kenal juga dengan metode adsorpsi pada larutan. Prinsip kerja dari metode ini adalah menukarkan ion yang terdapat pada situs aktif pengemban dengan katalis logam. Tujuan dari metode ini yaitu memasukkan inti aktif yang berguna untuk menghilangkan senyawa berbahaya, selain itu juga bertujuan untuk menambah promotor. Reaksi pertukaran ion dilakukan dengan cara memasukkan ion logam kedalam arang aktif.

Adsorpsi juga mungkin terjadi dengan mekanisme pertukaran ion. Permukaan padatan dapat mengadsorpsi ion-ion dari larutan dengan mekanisme pertukaran ion. Oleh karena itu, ion pada gugus senyawa permukaan padatan adsorbennya dapat bertukar tempat dengan ion-ion adsorbat. Mekanisme pertukaran ini merupakan penggabungan dari mekanisme kemisorpsi dan fisisorpsi, karena adsorpsi jenis ini akan mengikat ion-ion yang diadsorpsi dengan ikatan secara kimia, tetapi ikatan ini mudah dilepaskan kembali untuk dapat terjadinya pertukaran ion.

\section{Perbedaan Metode Impregnasi dan Ion Exchange}

Penelitian oleh Anggoro et al., (2016) dalam "Effect of Co and Mo Loading by Impregnation and Ion Exchange Methods on Morphological Properties of Zeolite Y Catalyst" Pengembanan Co dan Mo pada katalis Y-Zeolit yang dibuat dengan menggunakan impregnasi dan metode pertukaran ion (ion exchange) tidak mengubah struktur katalis. Persentase kristalisasi katalis untuk katalis yang dibuat dengan metode pertukaran ion lebih tinggi, sedangkan keasaman katalis lebih tinggi untuk katalis yang dibuat dengan menggunakan impregnasi. Hasil bahan bakar cair menggunakan metode impregnasi lebih besar daripada menggunakan metode pertukaran ion, namun komposisi fraksi bensin lebih besar jika menggunakan metode pertukaran ion. Hasil ini dapat disimpulkan bahwa hasil bahan bakar cair dan komposisi fraksi bensin dari hydrocracking tar batubara tergantung pada keasaman katalis. Jika keasaman katalis tinggi, hasil bahan bakar cair meningkat, namun komposisi fraksi bensin menurun (Anggoro et al., 2016).

\section{Studi Kinetika}

Reaksi katalitik fase gas - solid akan terjadi bila sedikitnya satu atau seringkali semua reaktan harus bersinggungan dengan permukaan katalis melalui proses adsorpsi. Proses adsorpsi dapat terjadi secara fisika 
maupun kimia. Untuk persamaan reaksi katalitik reaktan menjadi produk, laju reaksi secara umum tergantung pada regim-regim reaksi sebagai berikut :

1. Kinetika reaksi permukaan didalam atau diluar partikel. Reaksi ini termasuk proses adsorpsi reaktan dan desorpsi dari produknya.

2. Tahanan diffusi didalam partikel (pore diffusion) yang dapat menghambat reaktan.

3. Difusi pada film disekitar partikel

4. Beda suhu dibagian dan luar partikel. Hal ini disebabkan oleh panas yang dilepas pada reaksi eksotermik

5. Beda suhu dibagian luar katalis dan badan fasa gas. Partikel mungkin suhunya seragam disetiap bagian tetapi lebih panas daripada gas sekelilingnya.

Percobaan ini dilaksanakan pada tiga temperatur yang berbeda $\left(450,500,550^{\circ} \mathrm{C}\right)$ dengan laju alir mulamula $\left(\mathrm{FA}_{0}\right)$ yang berbeda. Temperatur reaksi mempengaruhi harga konstanta laju reaksi sesuai dengan persamaan Arhenius $\mathrm{k}=\mathrm{k}_{\mathrm{o}} \mathrm{e}^{\mathrm{E}}{ }^{\mathrm{E} / \mathrm{RT}}$. Kenaikan temperatur berbanding lurus dengan kenaikan laju reaksi.

Dimana :

$\mathrm{k}_{0}=$ faktor frekwensi

$\mathrm{Ea}=$ energi aktivasi

$\mathrm{R}=$ tetapan gas umum

$\mathrm{T}=$ temperatur.

Persamaan Arhenius dapat dinyatakan secara logaritma sebagai berikut:

$\ln k=\ln k_{0}-\frac{E a}{R T}$

Energi aktivasi (E) diperoleh dari plot $\ln \mathrm{k}$ vs $1 / \mathrm{T}$ diperoleh intersep $\ln \mathrm{k}_{0}$ dan slope $\mathrm{Ea} / \mathrm{R}$ digunakan untuk menentukan Ea dan faktor frekwensi $\left(\mathrm{k}_{0}\right)$ (Nurjanah and Ifa, 2012).

\section{Waktu Dan Tempat Penelitian}

Penelitian ini dilaksanakan selama semester genap tahun ajaran 2018/2019, yaitu dari bulan April 2018 sampai dengan Oktober 2018. Penelitian ini dilaksanakan di Laboratorium Pusat Studi Energi dan Nanomaterial Universitas Jambi.

\section{Alat dan Bahan}

Alat yang digunakan dalam penelitian ini adalah reaktor perengkahan. Selain itu Seperangkat Alat Penyaringan Minyak Jelantah, Hot Plate \& Magnetic Stirrer, Gelas Beaker $500 \mathrm{ml}$, Gelas Ukur $100 \mathrm{ml}$, Neraca Analitik, Cawan Porselin, Spatula, Erlenmeyer, Cawan Porselin Datar. Semua alat-alat ini tersedia di Laboratorium Energi dan Nano Material Universitas Jambi

Bahan yang digunakan dalam penelitian ini adalah, Minyak Jelantah, Arang aktif, $\mathrm{Na}_{2} \mathrm{CO}_{3}$ (Soda api), $\mathrm{CH}_{3} \mathrm{COOH}$ (Asam asetat), $\mathrm{Co}\left(\mathrm{NO}_{3}\right)_{2} \cdot 6 \mathrm{H}_{2} \mathrm{O}$ (Cobalt (II) Nitrate Hexahydrate), Aquades, Kertas Saring, Kertas $\mathrm{pH}$, gas nitrogen, air.

\section{PROSEDUR KERJA}

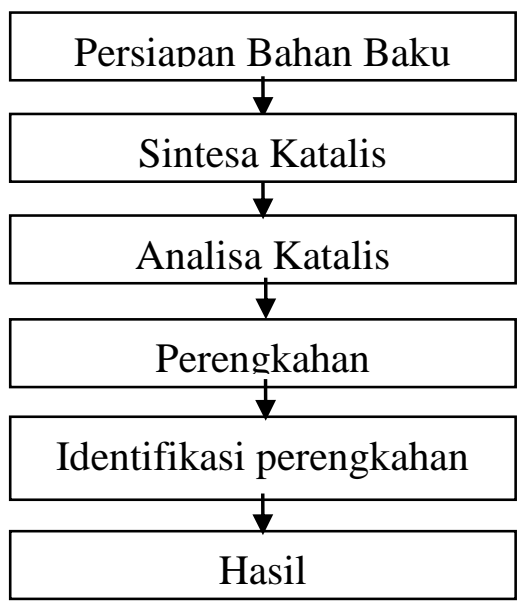




\section{Persiapan Bahan Baku}

Minyak jelantah yang didapat dari bekas penggorengan rumah tangga. Penyaringan minyak jelantah dilakukan dengan alat adsorpsi yang dirangkai dari pipa 2 inch yang di lengkapi dengan mesh dan kertas saring. Di isi arang dari cangkang kelapa sawit sebanyak 350 gr. Dilakukan penyaringan masing-masing sebanyak $660 \mathrm{ml}$.

\section{Sintesa Katalis}

Aktivasi Arang

Minyak jelantah yang didapat dari bekas penggorengan rumah tangga. Penyaringan minyak jelantah dilakukan dengan alat adsorpsi yang dirangkai dari pipa 2 inch yang di lengkapi dengan mesh dan kertas saring. Di isi arang dari cangkang kelapa sawit sebanyak 350 gr. Dilakukan penyaringan masing-masing sebanyak $660 \mathrm{ml}$.

\section{Modifikasi Katalis Arang aktif metode Ion Exchange dengan variasi konsentrasi Larutan Co}

Pembuatan Katalis Co-Arang Aktif terlebih dahulu dengan membuat larutan garam Co-Nitrat dengan perbandingan mol masing-masing zat. Larutan Co-Nitrat dibuat terlebih dahulu dengan variasi konsentrasi, yaitu 1\%, 2\% dan 3\% masing-masing dilarutkan dalam $100 \mathrm{ml}$ aquades.

Arang aktif dan larutan yang mengandung logam Co dicampurkan dengan perbandingan 1;10 kemudian distirrer selama 24 Jam. Setelah distirrer, Katalis Co-Arang Aktif disaring dan dicuci. Padatan katalis yang dihasilkan dikeringkan pada suhu $105^{\circ} \mathrm{C}$ selama $12 \mathrm{jam}$.

\section{Perengkahan}

Minyak jelantah dimasukkan kedalam reaktor perengkahan yang sebelumnya telah di isi dengan katalis Co-Arang Aktif dengan perbandingan 1:10. Reaksi perengkahan dilakukan selama 60 menit dengan variasi temperatur reaksi $450^{\circ} \mathrm{C}, 500^{\circ} \mathrm{C}, 550^{\circ} \mathrm{C}$. Cairan Hasil Perengkahan (CHP) diambil setiap per lima menit pada konsentrasi katalis $2 \%$ dan 3\%, sedangkan pada konsentrasi 1\% CHP diambil setiap per 15 menit dan perengkahan dilakukan selama 75 menit.

\section{Hasil Penelitian dan Pembahasan}

\section{Pre-treatment Bahan Baku}

Bahan baku yang digunakan dalam penelitian ini yaitu Minyak Jelantah limbah penggorengan rumah tangga. Minyak jelantah tersebut telah dipakai sebanyak 3 kali penggorengan. Pemanasan pada suhu tinggi selama penggorengan mengakibatkan minyak goreng mengalami kerusakan. Kerusakan tersebut dapat dilihat dengan berubahnya warna dari kuning menjadi coklat kehitaman, kenaikan kekentalan, dan kenaikan asam lemak bebas. Pemanfaatan minyak jelantah sebagai bahan baku penelitian ini dengan melakukan pemurnian minyak dengan metode adsorpsi.

Penyaringan Minyak Jelantah menggunakan adsorben arang aktif. Hasil penyaringan minyak jelantah dapat dilihat pada Gambar 1. dibawah ini.

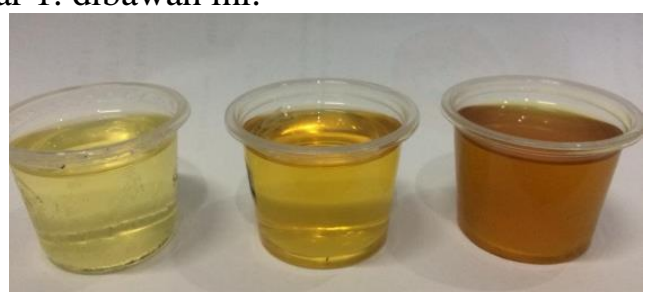

(a)

(b)

(c)

Gambar 1. Perbedaan fisik minyak (a) Minyak goreng baru, (b) Minyak jelantah setelah disaring (c) Minyak jelantah sebelum disaring 
Pada gambar 1 dapat dilihat bahwa terdapat perbedaan Minyak jelantah sebelum dan sesudah disaring. Minyak jelantah yang telah disaring berwarna kuning hampir bening seperti minyak goreng baru. Sedangkan minyak jelantah sebelum penyaringan berwarna kuning kecoklatan.

\section{Densitas Bahan}

Berdasarkan pengamatan secara visual untuk bahan baku berupa minyak jelantah dilakukan perhitungan densitas untuk mengetahui besaran massa jenis yang dinyatakan daalam berat per satuan volume. Data densitas dapat dapat dilihat tabel 1.

Tabel 1. Densitas Bahan Baku Perengkahan

\begin{tabular}{ccc}
\hline Bahan & $\begin{array}{c}\text { Berat bahan } \\
(\mathrm{gr})\end{array}$ & Densitas Bahan Baku (gr) \\
\hline Minyak Goreng Kemasan & 17.30 & 0.9534 \\
Minyak Jelntah Belum Disaring & 17.28 & 0.9494 \\
Minyak Jelantah Sudah Disaring & 17.30 & 0.9534 \\
Aquades & 17.44 & 0.9814 \\
\hline
\end{tabular}

Berdasarkan tabel 1 dapat dibandingkan bahwa densitas minyak jelantah yang belum disaring lebih kecil dari pada minyak jelantah yang sudah disaring. Minyak jelantah yang telah disaring memiliki nilai densitas yang sama dengan minyak goreng kemasan.

\section{Preparasi dan Karakterisasi Katalis Aktivasi Arang}

Aktivasi arang bertujuan untuk menghilangkan senyawa nonkarbon sehingga diperoleh unsur karbon murni, memperbesar pori dengan cara memecahkan ikatan hidrokarbon atau mengoksidasi molekul- molekul permukaan sehingga karbon mengalami perubahan sifat, baik fisika maupun kimia, yaitu luas permukaannya bertambah besar dan berpengaruh terhadap daya adsorpsi. Proses aktivasi dilakukan aktivator $\mathrm{Na}_{2} \mathrm{CO}_{3}$

Pencucian karbon setelah aktivasi dilakukan untuk menghilangkan sisa residu organik, kontaminan, mineral dan sisa-sisa logam yang tertinggal dalam rongga pori. Oksida logam yang tertinggal didalam pori dapat mempengaruhi daya jerap karbon aktif pada senyawa tertentu (Setianingsih et al. 2008). Kemampuan adsorpsi juga akan meningkat bila $\mathrm{pH}$ diturunkan yaitu dengan menambah asam-asam mineral, karena kemampuan asam mineral akan mengurangi ionisasi asam organik tersebut (Sembiring et al. 2003).

Padatan katalis yang dihasilkan selanjutnya dialirkan steam pada suhu $550^{\circ} \mathrm{C}$ selama 6 jam. Tujuan dialirkan steam adalah untuk menghilangkan sisa-sisa pengotor dan logam-logam pengotor. Padatan Katalis berupa padatan berwarna hitam.

\section{Modifikasi Katalis Arang aktif metode Ion Exchange dengan variasi konsentrasi Larutan Co}

Arang aktif direndam menggunakan larutan kobalt nitrat melalui metode ion exchange. Preparasi diawali dengan menyiapkan larutan $\mathrm{Co}\left(\mathrm{NO}_{3}\right)_{2} \cdot 6 \mathrm{H}_{2} \mathrm{O}$ dengan tiga variasi yaitu $1 \%, 2 \%$ dan $3 \%$. Kemudian diaduk menggunakan stirer sampai homogen selama 24 jam. Langkah selanjutnya adalah menyaring larutan Co-Arang menggunakan pompa vakum, kemudian dicuci sampai pH 7 (netral). Filtrat hasil penyaringan disimpan untuk metode impregnasi. Padatan katalis dikeringkan menggunakan oven selama 12 jam.

Pengembanan logam transisi pada karbon aktif bertujuan untuk memperbanyak jumlah sisi aktif (active site) pada katalis, sehingga pada saat perengkahan kontak antara reaktan dengan katalis akan semakin besar. Dengan begitu katalis akan semakin mempercepat dalam proses pembentukan produk.

\section{Karakterisasi Dengan SEM-EDX}

Analisa bentuk morfologi permukaan dan material penyusun katalis Co-Arang menggunakan Scanning Electron Microscopy dan Energy Dispersive X-ray Spectroscopy (EDX). Hasil analisa SEM karbon dari cangkang kelapa sawit dapat dilihat pada gambar 2. dan karbon yang di ion exchange dengan kobalt dapat dilihat pada gambar 3. sampai 5. 


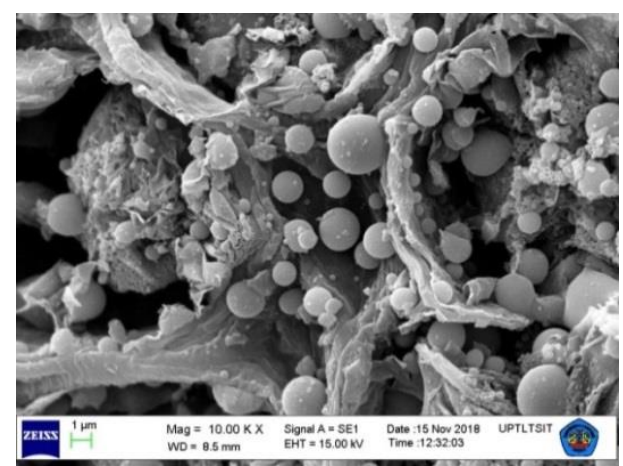

Gambar 2. Morfologi Karbon aktif menggunakan SEM-EDX perbesaran 10.000x

Untuk gambar 2 merupakan struktur permukaan dari karbon aktif pada perbesaran 10000x, yang memperlihatkan bahwa karbon aktif berbentuk rongga dan memilki pori. Jarak antara pori yaitu $10 \mu \mathrm{m}$. Walaupun telah diketahui bahwa pori arang aktif telah terisi setelah diberi perlakuan perendaman, perlu dilakukan pengujian lebih lanjut untuk mengetahui unsur yang mengisi arang aktif tersebut. Pengujian dilakukan secara kualitatif dengan menggunakan EDX. Hasil analisa dengan EDX dirangkum dalam Tabel 2 berikut

Tabel 2. Unsur Karbon aktif dari cangkang kelapa sawit hasil analisa EDX

\begin{tabular}{ccc}
\hline No. & Unsur & Persen Berat $(\%)$ \\
\hline 1. & $\mathrm{Si}$ & 35,35 \\
2. & $\mathrm{C}$ & 62,32 \\
3. & $\mathrm{P}$ & 2,14 \\
4. & $\mathrm{Ca}$ & 0,20 \\
\hline
\end{tabular}

Berdasarkan Tabel 2. hasil yang tertera pada EDX, untuk karbon aktif didominasi oleh unsur C (karbon) sebanyak 62,32\% dan untuk sisanya terdapat unsur lain seperti Si sebesar 35,35\% ; P sebesar 2,14\% dan Ca sebanyak 0,20\%.

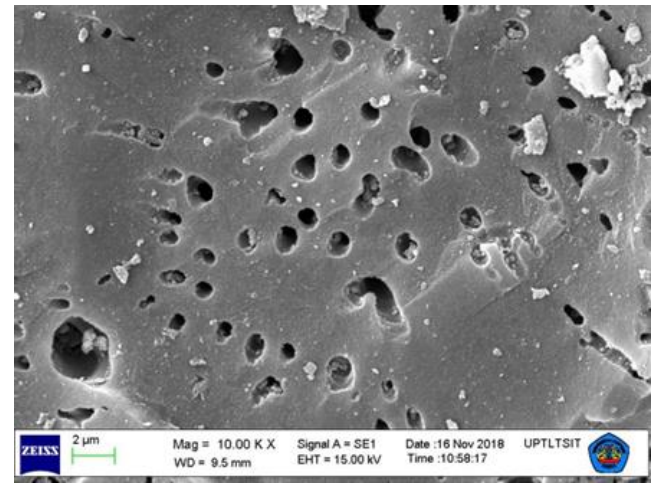

Gambar 3. Morfologi katalis Co-Arang 1\% menggunakan SEM-EDX perbesaran 10.000x

Berdasarkan Gambar 3. yang telah dilakukan analisa menggunakan SEM, kobalt dengan konsentrasi larutan $1 \%$ tersebar dan menempel pada permukaan karbon aktif sehingga menutupi pori-pori karbon aktif tersebut. Berbeda dengan karbon aktif, pada komposit Co-Arang 1\% menunjukkan hasil morfologi yang permukaannya lebih tidak rata dibandingkan dengan permukaaan karbon aktif. Jarak antara pori pada pada perbesaran 10.000x yaitu $2 \mu \mathrm{m}$. Berdasarkan hasil SEM ini terlihat bahwa morfologi pori pada katalis CoArang 1\% telah terbentuk dengan diameter berkisar 2-10 $\mu \mathrm{m}$.

Untuk mengetahui apakah kobalt teremban pada karbon aktif, maka dilakukan pengujian dengan menggunakan EDX untuk mengetahui komponen yang terkandung didalam katalis Co-Arang $1 \%$. Hasil pengujian dapat dilihat pada tabel 2 
Tabel 3 Unsur Co-Arang 1\% hasil analisa EDX

\begin{tabular}{ccc}
\hline No. & Unsur & Persen Berat $(\%)$ \\
\hline 1. & $\mathrm{Si}$ & 3,19 \\
2. & $\mathrm{C}$ & 93,30 \\
3. & $\mathrm{P}$ & 2,35 \\
4. & $\mathrm{Ca}$ & 0,31 \\
5. & $\mathrm{Co}$ & 0,86 \\
\hline
\end{tabular}

Berdasarkan Tabel 3. data analisa EDX diatas terhadap katalis Co-Arang 1\%, logam kobalt yang teremban ke dalam pori-pori karbon sebanyak $0,86 \%$ dari total keseluruhan senyawa yang terdapat pada katalis Co-Arang $1 \%$.

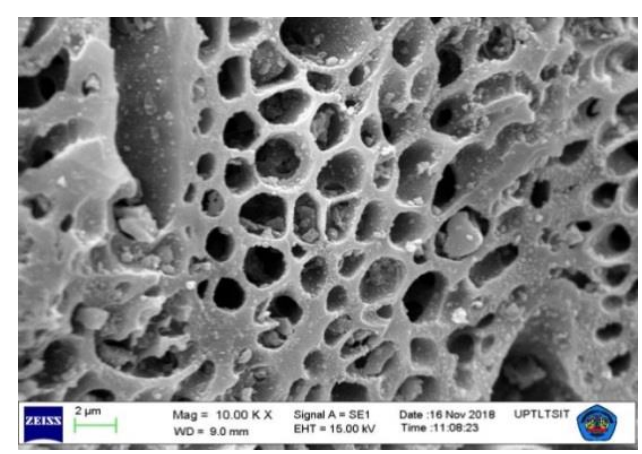

Gambar 4. Morfologi katalis Co-Arang 2\% menggunakan SEM-EDX perbesaran 10.000x

Berdasarkan Gambar 4. yang telah dilakukan analisa menggunakan SEM, kobalt dengan konsentrasi larutan 2\% tersebar dan menempel pada permukaan karbon aktif tetapi tidak menutupi pori-pori karbon aktif tersebut. Jarak antara pori pada perbesaran 3000x yaitu $10 \mu \mathrm{m}$ dan pada perbesaran 10.000x yaitu $2 \mu \mathrm{m}$. Berdasarkan hasil SEM ini terlihat bahwa morfologi pori pada katalis Co-Arang 2\% telah terbentuk dengan diameter berkisar 2-10 $\mu \mathrm{m}$.

Untuk mengetahui apakah kobalt teremban pada karbon aktif, maka dilakukan pengujian dengan menggunakan EDX untuk mengetahui komponen yang terkandung didalam katalis Co-Arang 2\%. Hasil pengujian dapat dilihat pada Tabel 4.

Tabel 4. Unsur Co-Arang 2\% hasil analisa EDX

\begin{tabular}{ccc}
\hline No. & Unsur & Persen Berat $(\%)$ \\
\hline 1. & $\mathrm{Si}$ & 2,09 \\
2. & $\mathrm{C}$ & 92,33 \\
3. & $\mathrm{P}$ & 3,09 \\
4. & $\mathrm{Ca}$ & 0,25 \\
5. & $\mathrm{Co}$ & 1,99 \\
6. & $\mathrm{Al}$ & 0,16 \\
7. & $\mathrm{Mg}$ & 0,10 \\
\hline
\end{tabular}

Berdasarkan Tabel 4. data analisa EDX diatas terhadap katalis Co-Arang 2\%, logam kobalt yang teremban ke dalam pori-pori karbon sebanyak 1,99\% dari total keseluruhan senyawa yang terdapat pada katalis Co-Arang 2\%. Hasil ini menunjukkan peningkatan persentase logam kobalt yang teremban pada karbon aktif. Unsur lain yang terdapat pada Co-Arang 2\% sama seperti pada karbon aktif. Sisa kandungan

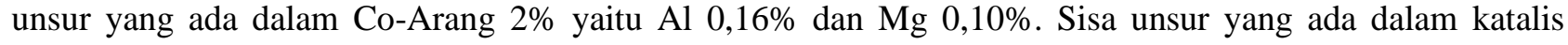
tersebut merupakan pengotor yang dihasilkan. 


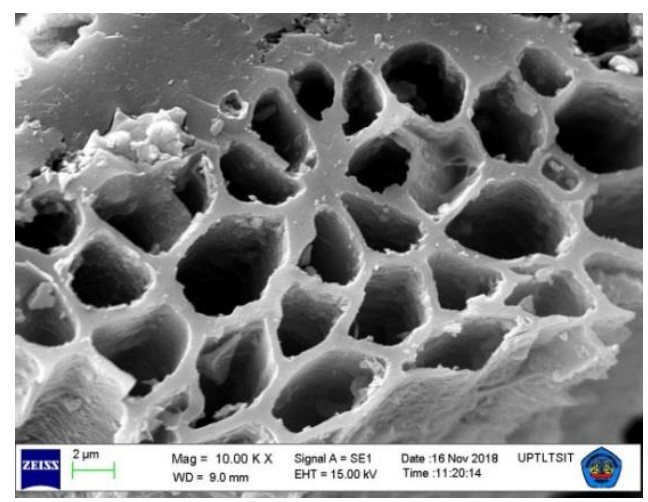

Gambar 5. Morfologi katalis Co-Arang 3\% menggunakan SEM-EDX Perbesaran 10.000x

Gambar 5. yang telah dilakukan analisa menggunakan SEM, kobalt dengan konsentrasi larutan 3\% tersebar dan menempel pada permukaan karbon aktif tetapi tidak menutupi pori-pori karbon aktif tersebut. Jarak antara pori pada perbesaran 3000x yaitu $10 \mu \mathrm{m}$ dan pada perbesaran 10.000x yaitu $2 \mu \mathrm{m}$. Berdasarkan hasil SEM ini terlihat bahwa morfologi pori pada katalis Co-Arang 3\% telah terbentuk dengan diameter berkisar 2-10 $\mu \mathrm{m}$. Namun, rongga pori tersebut tidak tersebar merata hal ini disebabkan sedikitnya jumlah Co $3 \%$ yang teremban yaitu sebesar $0,11 \%$.

Untuk mengetahui apakah kobalt teremban pada karbon aktif, maka dilakukan pengujian dengan menggunakan EDX untuk mengetahui komponen yang terkandung didalam katalis Co-Arang 3\%. Hasil pengujian dapat dilihat pada Tabel 5.

Tabel 5. Unsur Co-Arang 3\% hasil analisa EDX

\begin{tabular}{ccc}
\hline No. & Unsur & Persen Berat $(\%)$ \\
\hline 1. & $\mathrm{Si}$ & 0,29 \\
2. & $\mathrm{C}$ & 97,70 \\
3. & $\mathrm{P}$ & 1,72 \\
4. & $\mathrm{Ca}$ & 0,06 \\
5. & $\mathrm{Co}$ & 0,11 \\
6. & $\mathrm{Al}$ & 0,08 \\
7. & $\mathrm{Mg}$ & 0,04 \\
\hline
\end{tabular}

Berdasarkan Tabel 5. data analisa EDX diatas terhadap katalis Co-Arang 3\%, logam kobalt yang teremban ke dalam pori-pori karbon sebanyak $0,11 \%$ dari total keseluruhan senyawa yang terdapat pada katalis Co-Arang 3\%. Hasil ini menunjukkan penurunan persentase logam kobalt yang teremban pada karbon aktif. Secara teoritis, semakin meningkat konsentrasi logam maka semakin tinggi pula persentase logam yang teremban ke pori-pori karbon aktif. Penurunan persentase ini terjadi karena setelah penyaringan larutan kobalt dengan arang aktif dicuci dengan aquades berlebih sehingga $\mathrm{pH}$ menjadi tidak netral. Sedangan $\mathrm{pH}$ larutan kobalt adalah 6. Untuk data kandungan unsur per konsentrasi katalis dapat dilihat pada tabel 6.

Tabel 6 Data SEM-EDX Per Konsentrasi Katalis

\begin{tabular}{ccccc}
\hline No & Kandungan Unsur EDX & Co $1 \%$ & Co 2\% & Co 3\% \\
\hline 1. & $\mathrm{Si}$ & 3,19 & 2,09 & 0,29 \\
2. & $\mathrm{C}$ & 93,30 & 92,33 & 97,70 \\
3. & $\mathrm{P}$ & 2,35 & 3,09 & 1,72 \\
4. & $\mathrm{Ca}$ & 0,31 & 0,25 & 0,06 \\
5. & $\mathrm{Co}$ & 0,86 & 1,99 & 0,11 \\
6. & $\mathrm{Al}$ & 0,00 & 0,16 & 0,08 \\
7. & $\mathrm{Mg}$ & 0,00 & 0,10 & 0,04 \\
\hline
\end{tabular}


Berdasarkan tabel 6 unsur Karbon menurun seiring dengan meningkatnya konsentrasi larutan logam Co, namun pada konsentrasi larutan logam Co $3 \%$ persentase karbon lebih banyak dikarenakan unsur Co yang teremban lebih sedikit. Pada konsentrasi larutan logam Co $1 \%$ tidak terbentuk unsur $\mathrm{Al}$ dan $\mathrm{Mg}$. Pengembanan logam Co dengan metode Ion Exchange dapat menurunkan kandungan silika pada arang aktif dengan bertambahnya konsentrasi larutan logam Co. Kandungan silika sangat berpengaruh pada kualitas arang yang dihasilkan. Keberadaan silika dapat menyebabkan terjadinya penyumbatan pori-pori pada arang sehingga luas permukaan arang menjadi berkurang (Solihudin, et al, 2015)

\section{Karakterisasi Dengan XRD}

Analisis menggunakan alat difraktometer sinar-X (XRD) didasarkan pada pola difraksi dari paduan atau senyawa yang dihasilkan oleh proses difraksi, ukuran panjang gelombang sinar-X harus tidak berbeda jauh dengan jarak antar atom di dalam kristal, sehingga pola berulang dari kisi kristal akan berfungsi seolaholah seperti kisi difraksi untuk panjang gelombang sinar-X. Difraktogram XRD pada arang sebelum di steam dan arang aktif setelah disteam disajikan pada Gambar 6 dan 7, sedangkan difraktogram XRD katalis CoArang aktif 1\%,2\%, dan 3\% disajikan pada Gambar 8, 9, dan 10.

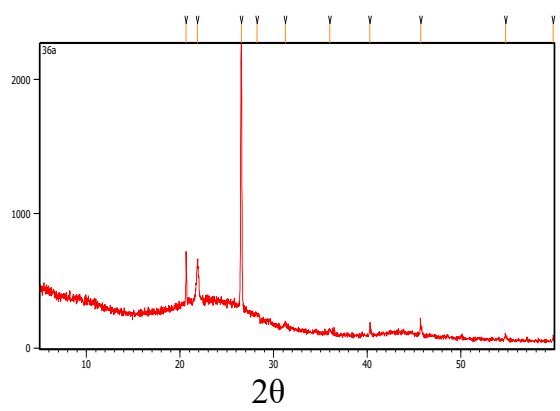

Gambar 6. Difraktogram XRD Arang aktif sebelum Steam

Berdasarkan gambar 6. Hasil analisis menunjukkan bahwa Arang berada pada fasa cristobalite, hal ini ditunjukkan oleh tingginya puncak intensitas pada posisi $2 \theta=26.5395$

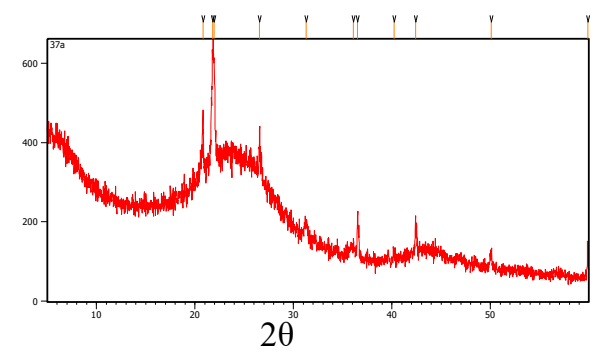

Gambar 7. Difraktogram XRD Arang aktif sesudah Steam

Gambar 7. merupakan pola difraksi sinar-X arang aktif sesudah steam. Dari difraktogram arang aktif dapat diketahui bahwa arang aktif. Mempunyai bentuk amorf. Hal tersebut ditunjukan dari hasil pola XRD karbon aktif yang diperoleh bentuknya tidak beraturan, dimana hal ini merupakan ciri dari amorf. Meskipun tidak dihasilkan puncak-puncak yang spesifik, akan tetapi masih dihasilkan sudut-sudut $2 \theta$ yang dapat terbaca yaitu 20.8167, 21.8070, 21.9576, 26.5576, 31.2917, 36.0734, 36.5082, 40.2165, 42.4083, 50.0772, dan 59.8601.

Berbeda dengan arang aktif, pada difraktogram arang aktif yang telah teremban Co, sudut-sudut yang dihasilkan lebih sedikit seperti yang terlihat pada gambar 8, 9 dan 10. 


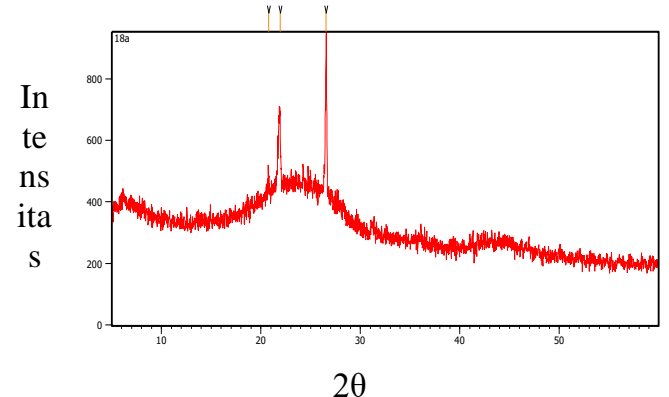

Gambar 8. Difraktogram XRD Katalis Co-Arang $1 \%$

Dari gambar 8 . dapat diketahui sudut-sudut $2 \theta$ yang dihasilkan dari Co-Arang $1 \%$ yaitu $20.7521,21.9227$ dan 26.5515 . Sudut $2 \theta$ Co-Arang $1 \%$ lebih sedikit dibandingan dengan arang aktif tetapi tidak mengalami pergeseran. Dengan Puncak Intensitas pada $2 \theta=26.5515$.

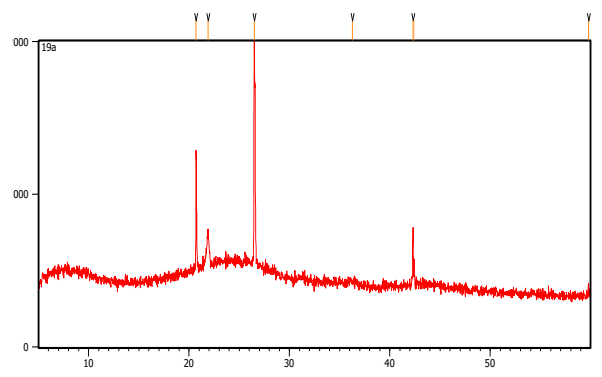

Gambar 9. Difraktogram XRD Katalis Co-Arang 2\%

Dari gambar 9. dapat diketahui sudut-sudut $2 \theta$ yang dihasilkan dari Co-Arang $2 \%$ yaitu 20.7002, 21.8803, 26.4862, 36.2806, 42.3005, 42.4073, dan 59.7788. Dengan Puncak Intensitas pada $2 \theta=26.4862$

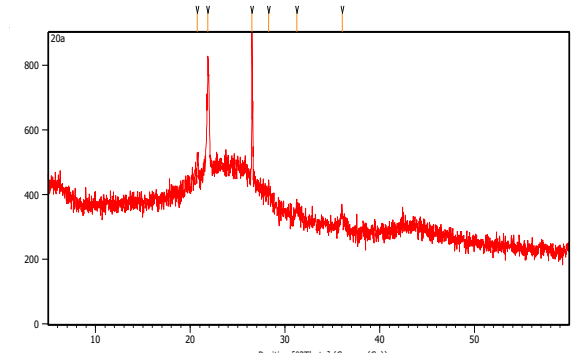

Gambar 10. Difraktogram XRD Katalis Co-Arang 3\%

Dari gambar 10. dapat diketahui sudut-sudut $2 \theta$ yang dihasilkan dari Co-Arang $3 \%$ yaitu 20.7294, 21.8542, 26.5079, 28.2620, 31.2490, 36.0285. Dengan Puncak Intensitas pada $2 \theta=26.5079$. Berdasarkan hasil karakterisasi yang diperoleh, arang aktif menunjukkan hasil yaitu berbentuk amorf. Pada arang aktif yang teremban logam Co pada konsentrasi $1 \%, 2 \%$ dan $3 \%$ juga berebntuk amorf.

\section{Perengkahan Minyak Jelantah \\ Perengkahan Termal}

Perengkahan termal dilakukan tanpa menggunakan katalis selama 60 menit. Untuk hasil CHP pada suhu $450^{\circ} \mathrm{C}$ adalah $18,77 \mathrm{gr}$, pada suhu $500^{\circ} \mathrm{C}$ adalah 24,56 gr dan pada suhu $550^{\circ} \mathrm{C}$ adalah $27,81 \mathrm{gr}$. Persen Konversi yang dihasilkan untuk suhu $450^{\circ} \mathrm{C}$ adalah $35,60 \%$, pada suhu $500^{\circ} \mathrm{C}$ adalah $47,15 \%$ dan pada suhu $550^{\circ} \mathrm{C}$ adalah 52,34\%. Perengkahan termal menghasilkan Cairan Hasil Perengkahan (CHP) dan Gas. CHP hasil perengkahan beku jika dimasukkan ke dalam kulkas.

Tabel 7. Hasil CHP perengkahan termal

\begin{tabular}{|c|c|c|c|}
\hline No & Bahan Baku (gr) & Suhu $\left({ }^{\circ} \mathrm{C}\right)$ & $\mathrm{CHP}(\%)$ \\
\hline
\end{tabular}




\begin{tabular}{llll}
\hline 1. & 450 & 35,60 \\
2. & Minyak Jelantah (50) & 500 & 47,15 \\
3. & 550 & 52,34 \\
\hline
\end{tabular}

Berdasarkan tabel 7. diatas temperatur dapat meningkatkan Konversi biofuel, tetapi dengan kenaikan temperatur yang cukup tinggi Konversi biofuel yang dihasilkan cenderung berkurang. Hal ini disebabkan karena pada temperatur yang tinggi terjadi peningkatan pada produk senyawa alkana rantai pendek $\mathrm{C}_{1}-\mathrm{C}_{4}$ yang berwujud gas. Pembentukan senyawa ini sangat dipengaruhi oleh faktor waktu dan temperatur proses, rantai C-C dari fraksi minyak ringan akan terputus pada temperatur tinggi (Hartiati, 2006).

\section{Perengkahan Katalitik}

Perengkahan katalitik dilakukan dengan memvariasikan konsentrasi katalis Co-Arang 1\%, 2\% dan $3 \%$ dengan variasi suhu $450^{\circ} \mathrm{C}, 500^{\circ} \mathrm{C}$ dan $550^{\circ} \mathrm{C}$. Perbandingan katalis dan sampel, yaitu 1:10 dimana berat katalis adalah 2 gr dan berat bahan baku adalah 20 gr. Katalis yang digunakan merupakan modifikasi Arang aktif dengan penambahan logam yang digunakan yaitu logam Co. Proses perengkahan dilakukan di dalam reaktor flow yang terdapat dua reaktor yaitu Reaktor B2 (Horizontal) dan Reaktor B1 (Vertikal).

Tabel 8. Hasil perengkahan katalitik

\begin{tabular}{cccccc}
\hline Konsentrasi Larutan Co & Suhu $\left({ }^{\circ} \mathrm{C}\right)$ & $\begin{array}{c}\text { Konversi Total } \\
(\%)\end{array}$ & CHP $(\%)$ & Gas $(\%)$ & $\begin{array}{c}\text { Sisa Reaksi } \\
(\%)\end{array}$ \\
\hline \multirow{2}{*}{$1 \%$} & 450 & 97,42 & 47,55 & 49,87 & 2,58 \\
& 500 & 96,79 & 26,90 & 69,89 & 3,20 \\
& 550 & 92,38 & 21,04 & 71,34 & 7,61 \\
$2 \%$ & 450 & 61,65 & 2,38 & 59,27 & 38,35 \\
& 500 & 82,85 & 12,90 & 69,96 & 17,15 \\
$3 \%$ & 550 & 88,24 & 10,25 & 77,99 & 11,76 \\
& 450 & 88,25 & 9,80 & 78,45 & 11,75 \\
& 500 & 82,72 & 5,85 & 76,87 & 17,28 \\
\hline
\end{tabular}

Dari data tabel 8. dibuat grafik persen Konversi perengkahan katalitik pada setiap temperatur.

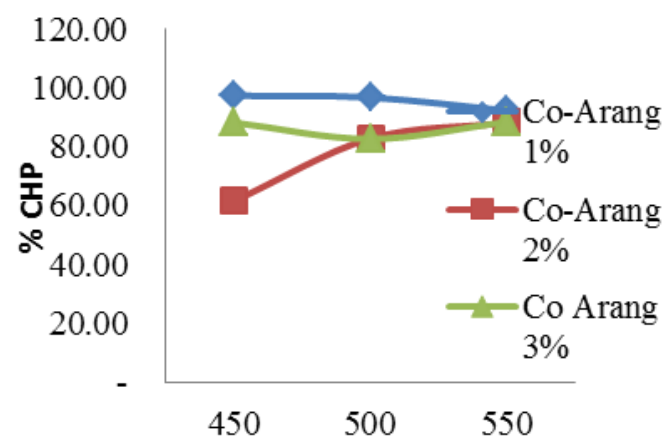

Gambar 11. Grafik Hubungan Temperatur serta Konsentrasi Larutan terhadap konversi total produk yang dihasilkan

Pada gambar 11 menunjukkan pengaruh temperatur serta Konsentrasi Larutan terhadap konversi total produk yang dihasilkan. Konversi total terdiri dari persen konversi Cairan Hasil Perengkahan dan persen konversi Gas. Pada konsentrasi Co-Arang 3\%, dengan kenaikan temperatur dapat meningkatkan kenaikan konversi produk, tetapi dengan kenaikan temperatur yang cukup tinggi konversi produk cenderung berkurang. Pada konsentrasi Co-Arang 2\%, dengan semakin tinggi temperatur, konversi produk meningkat.

\section{Pengaruh Temperatur terhadap Cairan Hasil Perengkahan}

Cairan Hasil Perengkahan atau yang disingkat dengan CHP merupakan produk utama hasil penelitian ini. Sedangkan sisa reaksi merupakan reaktan yang tidak berubah, sehingga sisa reaksi yang tersisa didalam reaktor tidak semuanya terengkah dengan baik sehingga tidak semua sampel ikut bereaksi, oleh 
sebab itu sisa reaksi yang tersisa didalam reaktor berwarna hitam dan kental. Perengkahan katalitik minyak jelantah juga menghasilkan produk berupa gas (uap yang tidak dapat terkondensasi).

Namun gas tersebut tidak ditampung karena gas yang keluar cukup banyak. Sehingga untuk menghitung gas yang dihasilkan selama perengkahan dapat dilakukan dengan cara berat sampel mula-mula dikurang dengan jumlah berat chp total dan berat sisa reaktan yang tidak bereaksi. Secara umum Konversi gas hasil perengkahan katalitik minyak jelantah cukup tinggi.

\section{Konversi CHP Perengkahan Katalitik dengan Co-Arang $1 \%$}

Untuk hasil CHP pada katalis Co-Arang $1 \%$ pada suhu suhu $450^{\circ} \mathrm{C}$ adalah 10,69 gr dengan CHP berwarna coklat dan cair, pada suhu $500^{\circ} \mathrm{C}$ menghasilkan CHP lebih sedikit yaitu 5,37 gr dan pada suhu $550^{\circ} \mathrm{C}$ adalah 4,53 gr dengan CHP berwarna coklat dan cair. Persen Konversi yang dihasilkan untuk suhu $450^{\circ} \mathrm{C}$ adalah $47,55 \%$, pada suhu $500^{\circ} \mathrm{C}$ adalah $26,90 \%$ dan pada suhu $550^{\circ} \mathrm{C}$ adalah $21,04 \%$. Untuk Konversi cairan hasil perengkahan (CHP) dengan katalis Co-Arang $1 \%$ terbesar didapatkan pada suhu $450^{\circ} \mathrm{C}$.

Tabel 9. Hasil CHP Perengkahan Katalitik (Co-Arang 1\%)

\begin{tabular}{cccccc}
\hline & & \multicolumn{4}{c}{ Yield } \\
\cline { 3 - 6 } No & Suhu $\left({ }^{\circ} \mathrm{C}\right)$ & Konversi total $(\%)$ & CHP $(\%)$ & Gas $(\%)$ & $\begin{array}{c}\text { Sisa Reaksi } \\
(\%)\end{array}$ \\
\hline 1. & 450 & 97,42 & 47,553 & 49,87 & 2,580 \\
2. & 500 & 96,79 & 26,904 & 69,89 & 3,206 \\
3. & 550 & 92,38 & 21,040 & 71,34 & 7,617 \\
\hline
\end{tabular}

Dari data tabel 9. dibuat grafik persen CHP perengkahan pada setiap temperatur.

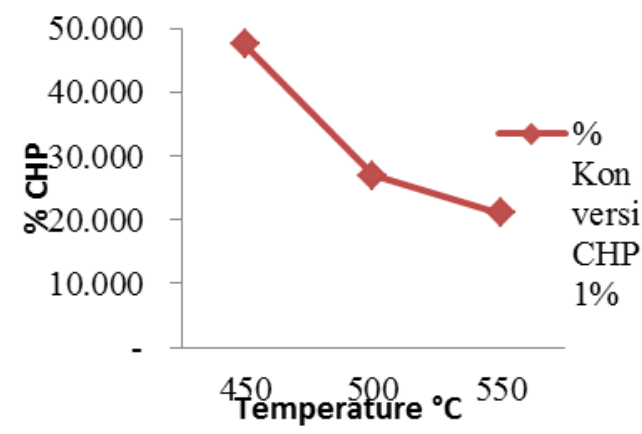

Gambar 12. Grafik Perengkahan Minyak Jelantah menggunakan katalis Co-Arang $1 \%$

Pada Gambar 12 menunjukkan pengaruh temperatur terhadap Pada perengkahan katalitik menggunakan katalis Co-Arang 1\%, dengan kenaikan temperatur persen konversi cenderung menurun. Pada perengkahan Minyak Jelantah menggunakan katalis Co-Arang 1\%, temperatur berbanding terbalik dengan persentase cairan hasil perengkahan, semakin tinggi temperatur maka persentase CHP semakin menurun.

\section{Konversi CHP Perengkahan Katalitik dengan Co-Arang $2 \%$}

Untuk hasil CHP pada katalis Co-Arang $2 \%$ pada suhu suhu $450^{\circ} \mathrm{C}$ adalah $0,56 \mathrm{gr}$, pada suhu $500^{\circ} \mathrm{C}$ adalah 2,73 gr dan pada suhu $550^{\circ} \mathrm{C}$ adalah 2,09 gr. Persen Konversi yang dihasilkan untuk suhu $450^{\circ} \mathrm{C}$ adalah $2,38 \%$, pada suhu $500^{\circ} \mathrm{C}$ adalah $12,90 \%$ dan pada suhu $550^{\circ} \mathrm{C}$ adalah $10,25 \%$ Konversi cairan hasil perengkahan (CHP) terbesar didapatkan pada suhu $500^{\circ} \mathrm{C}$.

Tabel 10. Hasil CHP Perengkahan Katalitik (Co-Arang 2\%)

\begin{tabular}{cccccc}
\hline & & \multicolumn{4}{c}{ Yield } \\
\cline { 3 - 6 } No & Suhu $\left({ }^{\circ} \mathrm{C}\right)$ & Konversi total $(\%)$ & CHP $(\%)$ & Gas $(\%)$ & $\begin{array}{c}\text { Sisa Reaksi } \\
(\%)\end{array}$ \\
\hline 1. & 450 & 61,65 & 2,38 & 59,27 & 38,35 \\
2. & 500 & 82,85 & 12,90 & 69,96 & 17,15
\end{tabular}


Dari data tabel 10. dibuat grafik persen CHP perengkahan pada setiap temperatur

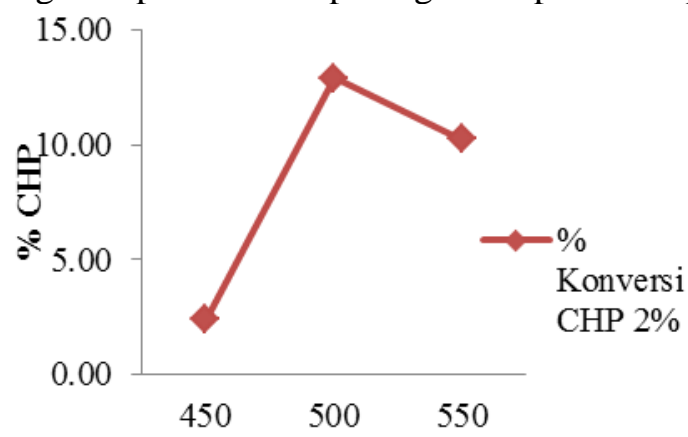

Gambar 13. Grafik Perengkahan Minyak Jelantah menggunakan katalis Co-Arang $2 \%$

Pada Gambar 13 menunjukkan pengaruh temperatur terhadap persen CHP yang dihasilkan. Dengan kenaikan temperatur, dapat meningkatkan persen CHP, tetapi pada kenaikan temperatur yang cukup tinggi, persen CHP cenderung berkurang. Menurut (Hartiati, 2006) pada temperatur yang tinggi terjadi peningkatan pada produk senyawa alkana rantai pendek $\mathrm{C}_{1}-\mathrm{C}_{4}$ yang berwujud gas. Pembentukan senyawa ini sangat dipengaruhi oleh faktor waktu dan temperatur proses, rantai C-C dari fraksi minyak ringan akan terputus pada temperatur tinggi.

\section{Konversi CHP Perengkahan Katalitik Co-Arang 3\%}

Hasil perengkahan katalitik mengunakan katalis Co-arang 3\% dapat dilihat pada tabel 11 dan grafik perbandingan \% CHP dengan temperatur pada gambar 14

Tabel 11. Hasil CHP Perengkahan Katalitik (Co-Arang 3\%)

\begin{tabular}{cccccc}
\hline No & $\begin{array}{c}\text { Suhu } \\
\left({ }^{\circ} \mathrm{C}\right)\end{array}$ & Konversi $(\%)$ & CHP $(\%)$ & Gas (\%) & $\begin{array}{c}\text { Sisa Reaksi } \\
(\%)\end{array}$ \\
\cline { 3 - 6 } & 450 & 88,25 & 9,80 & 78,45 & 11,75 \\
2. & 500 & 82,72 & 5,85 & 76,87 & 17,28 \\
3. & 550 & 88,55 & 18,64 & 69,91 & 11,45 \\
\hline
\end{tabular}

Dari data tabel 11. dibuat grafik persen CHP perengkahan pada setiap suhu

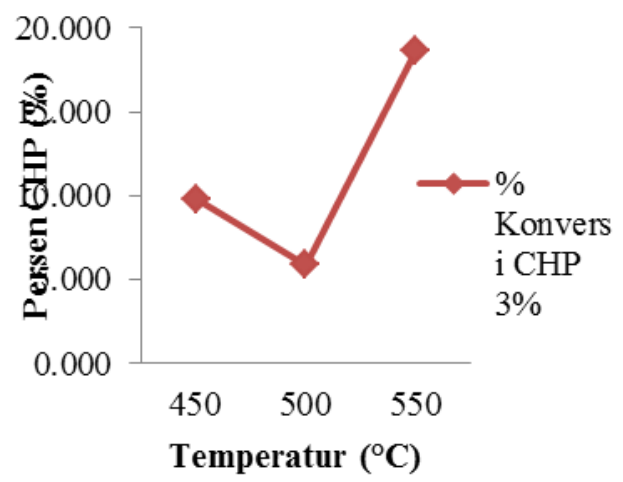

Gambar 14. Grafik Perengkahan Minyak Jelantah menggunakan katalis Co-Arang 3\%

Berdasarkan Tabel 10, Untuk hasil CHP pada katalis Co-Arang $3 \%$ pada suhu $450^{\circ} \mathrm{C}$ adalah $2,47 \mathrm{gr}$ dengan CHP berwarna coklat dan cair, pada suhu $500^{\circ} \mathrm{C}$ adalah 1,3 gr dengan CHP berwarna coklat dan cair serta pada suhu $550^{\circ} \mathrm{C}$ adalah 3,89 gr dengan CHP yang sama seperti CHP suhu-suhu sebelumnya. Persen Konversi yang dihasilkan untuk suhu $450^{\circ} \mathrm{C}$ adalah $9,80 \%$, pada suhu $500^{\circ} \mathrm{C}$ adalah $5,85 \%$ dan pada suhu 
$550^{\circ} \mathrm{C}$ adalah 18,64\%. Untuk Konversi cairan hasil perengkahan (CHP) dengan katalis Co-Arang 3\% terbesar didapatkan pada suhu $550^{\circ} \mathrm{C}$. Pada perengkahan katalitik menggunakan katalis Co-Arang 3\%, dengan kenaikan temperatur persen konversi cenderung menurun. Tetapi pada temperatur yang lebih tinggi, terjadi peningkatan persen CHP.

\section{Studi Kinetika}

\section{Menentukan ketetapan laju reaksi (nilai k)}

Berdasarkan persamaan laju reaksi maka untuk setiap pengambilan produk hasil reaksi katalitik dapat ditentukan besarnya konstanta laju reaksi pada temperatur tertentu. Selanjutnya untuk masing-masing variasi temperatur dapat dibuat grafik hubungan antara jumlah pengurangan reaktan lawan waktu pengambilan (t), dimana jumlah reaktan merupakan akumulasi pengurangan untuk setiap 5 menit pengambilan sampel produk. Untuk mendapatkan nilai $\mathrm{k}$ diperoleh dari hubungan persentase CHP per waktu, sehingga terbentuknya regresi dimana didapatkan juga nilai R. Nilai $R$ dengan Range $0,80-0,95$ termasuk dalam regresi linear sederhana, sedangkan jika nilai $\mathrm{R}<0,80$ termasuk regresi polynomial. Hubungan \% CHP vs waktu dapat dilihat pada grafik dibawah ini.

1. Co-Arang $1 \% 450^{\circ} \mathrm{C}$

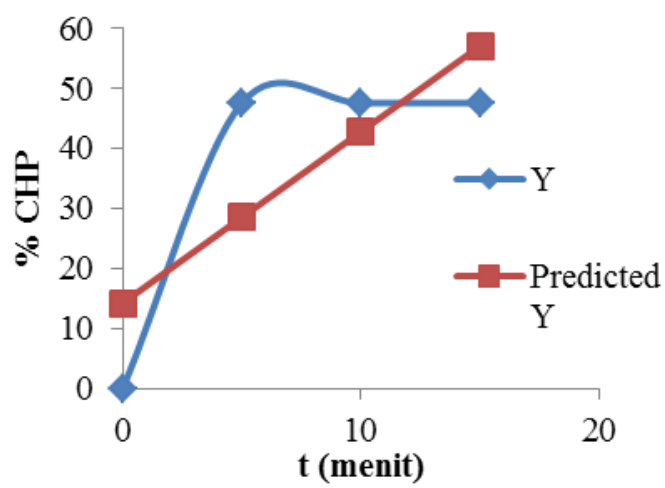

Gambar 15. Grafik \% CHP vs t (menit) katalis Co-Arang $1 \% 450^{\circ} \mathrm{C}$

2. Co-Arang $1 \% 500^{\circ} \mathrm{C}$

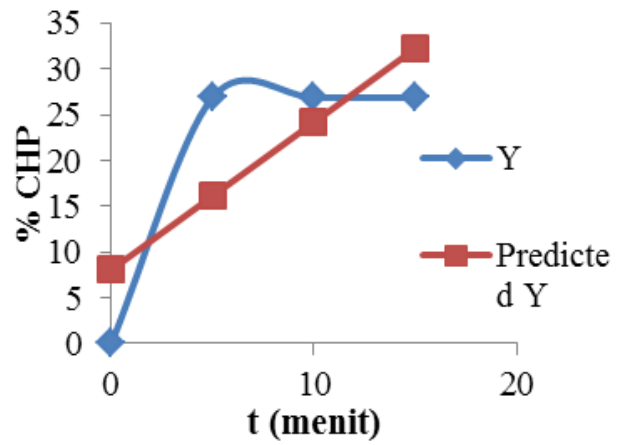

Gambar 16. Grafik \% CHP vs t (menit) katalis Co-Arang $1 \% 500^{\circ} \mathrm{C}$

3. Co-Arang $1 \% 550^{\circ} \mathrm{C}$ 


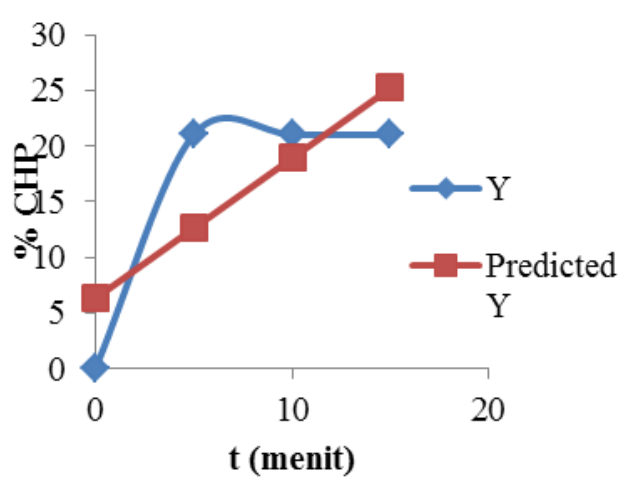

Gambar 17. Grafik \% CHP vs t (menit) katalis Co-Arang $1 \% 550^{\circ} \mathrm{C}$

4. Co-Arang $2 \% 450^{\circ} \mathrm{C}$

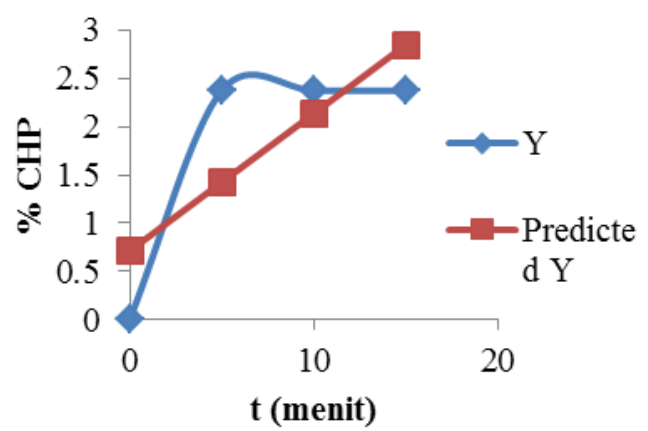

Gambar 18. Grafik \% CHP vs t (menit) katalis Co-Arang $2 \% 450^{\circ} \mathrm{C}$

5. Co-Arang $2 \% 500^{\circ} \mathrm{C}$

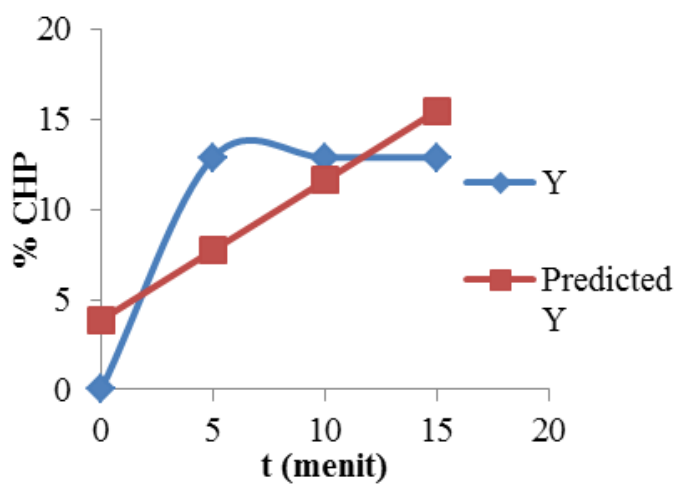

Gambar 19. Grafik \% CHP vs t (menit) katalis Co-Arang $2 \% 500^{\circ} \mathrm{C}$

6. Co-Arang $2 \% 550^{\circ} \mathrm{C}$ 


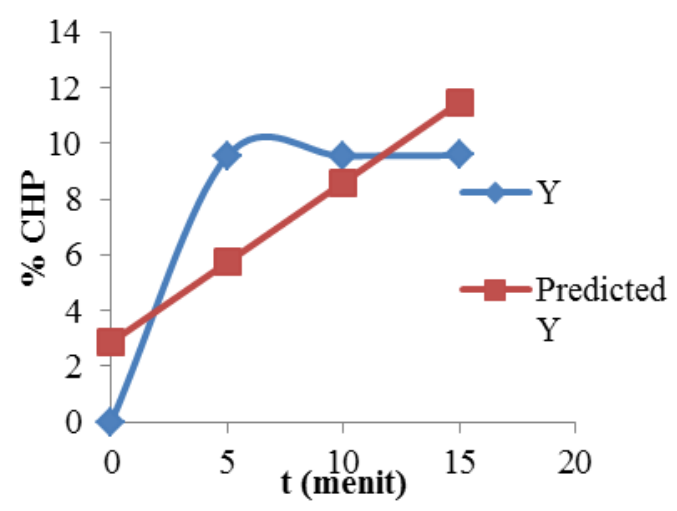

Gambar 20. Grafik \% CHP vs t (menit) katalis Co-Arang $2 \% 550^{\circ} \mathrm{C}$

7. Co-Arang $3 \% 450^{\circ} \mathrm{C}$

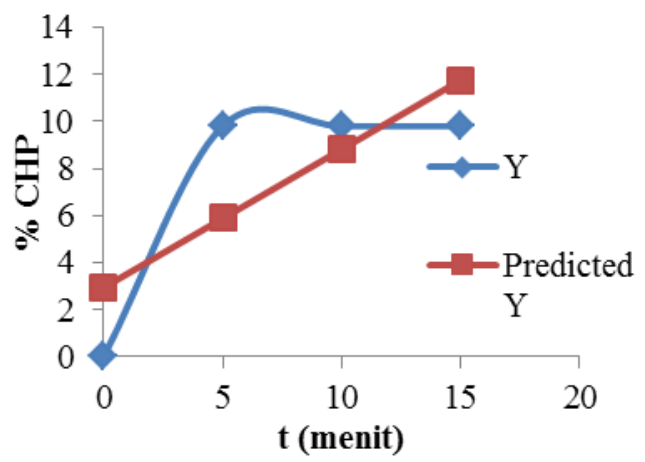

Gambar 21. Grafik \% CHP vs t (menit) katalis Co-Arang $3 \% 450^{\circ} \mathrm{C}$

8. Co-Arang $3 \% 500^{\circ} \mathrm{C}$

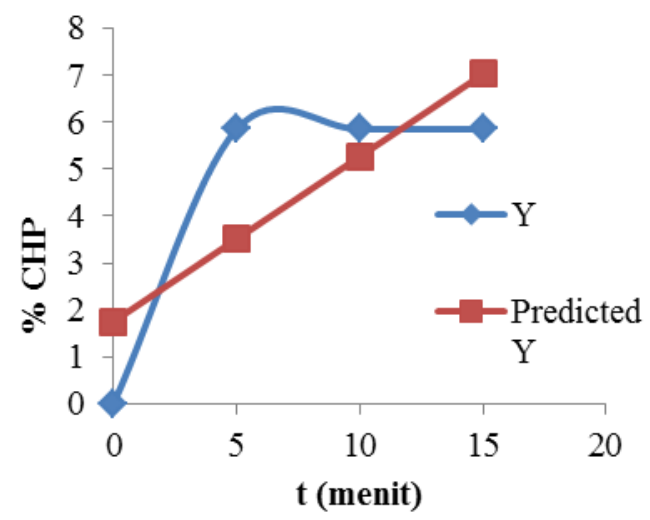

Gambar 22. Grafik \% CHP vs t (menit) katalis Co-Arang $3 \% 500^{\circ} \mathrm{C}$

9. Co-Arang $3 \% 550^{\circ} \mathrm{C}$ 


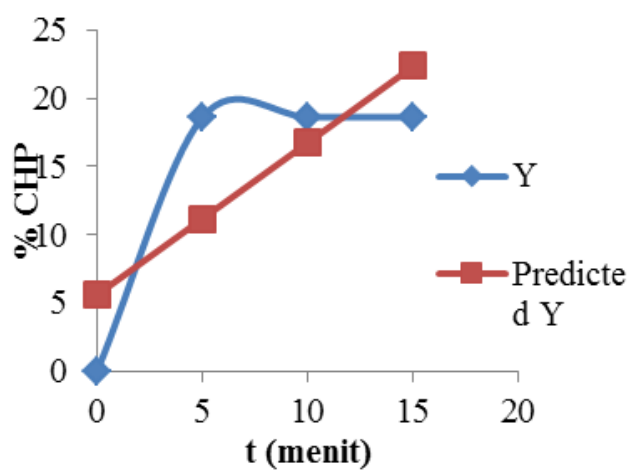

Gambar 23. Grafik \% CHP vs t (menit) katalis Co-Arang $3 \% 550^{\circ} \mathrm{C}$

Pada Gambar 15. sampai 23. menunjukkan bahwa katalis Co-Arang menunjukkan aktivitasnya yang maksimum pada 5 menit pertama dan selanjutnya katalis mengalami penurunan aktivitas yang ditandai dengan penurunan jumlah reaktan yang dikonversi menjadi produk. Dari grafik tersebut terlihat bahwa reaktan terkonversi menjadi produk yang cukup besar hanya terjadi pada 5 menit pertama reaksi berlangsung, sedangkan untuk 5 menit berikutnya hingga reaksi berakhir, pengurangan jumlah reaktan atau reaktan yang terkonversi menjadi produk sangat sedikit.

Berdasarkan dari grafik diatas hubungan persen CHP vs waktu, nilai R yang didapat dilihat pada tabel dibawah ini

Tabel 12. Nilai R Regresi Sederhana

\begin{tabular}{ccc}
\hline Katalis Co-Arang & Suhu $\left({ }^{\circ} \mathrm{C}\right)$ & Nilai R \\
\hline \multirow{2}{*}{$1 \%$} & 450 & 0,600 \\
& 500 & 0,600 \\
& 550 & 0,600 \\
$2 \%$ & 450 & 0,601 \\
& 500 & 0,600 \\
$3 \%$ & 550 & 0,750 \\
& 450 & 0,600 \\
& 500 & 0,658 \\
\end{tabular}

Berdasarkan tabel 12 nilai $\mathrm{R}$ rata-rata lebih kecil atau tidak mendekati 1. Sehingga untuk mendapatkan hasil yang lebih baik, menggunakan regresi polynomial. Persamaan regresi polynomial adalah

$$
y=a+k_{1} t+k_{2} t^{2}
$$

Dengan persamaan regresi polynomial, akan didapatkan nilai $\mathrm{R}$ mendekati satu.

\section{Energi Aktivasi}

Hubungan eksponensial antara $\mathrm{k}$ dan $\mathrm{T}$ dan dari persamaan Arhenius :

$$
\mathrm{k}=\mathrm{k}_{0} \mathrm{e}^{-\mathrm{E} / \mathrm{RT}}
$$

$\mathrm{k}_{0}$ merupakan faktor frekwensi, Ea adalah energi aktivasi, $\mathrm{R}$ adalah tetapan gas umum, dan $\mathrm{T}$ merupakan suhu absolut. Dari persamaan Arhenius tersebut dapat dicari harga Ea dimana $\ln \mathrm{k}=\ln \mathrm{k}_{0}{ }^{-\mathrm{Ea} / \mathrm{RT}}$, dimana hubungan antara $\mathrm{ln} \mathrm{k}$ versus $1 / \mathrm{T}$ dengan nilai $\mathrm{R}$ adalah 8,314 J/mol $\mathrm{K}$ diperoleh harga energi aktivasi. Untuk perengkahan katalitik menggunakan Co-Arang 1\%, 2\% dan 3\%, hubungan antara 1/T vs ln k dapat dilihat pada tabel 12 dan grafik.

Tabel 13. Hubungan $1 / \mathrm{T}$ vs $\ln \mathrm{k}$, Perengkahan Katalitik Minyak Jelantah Katalis Co-Arang $1 \%$

\begin{tabular}{cccc}
\hline $\mathrm{T}(\mathrm{K})$ & $1 / \mathrm{T}(\mathrm{K})$ & $\mathrm{k}$ & $\ln \mathrm{k}$ \\
\hline 723,15 & 0,001383 & 2,8532 & 1,04844 \\
773,15 & 0,001293 & 1,61423 & 0,47886 \\
823,15 & 0,001215 & 1,2624 & 0,23301 \\
\hline
\end{tabular}


Sesuai dengan persamaan Arhenius $\mathrm{k}=\ln \mathrm{k}_{0}$ - Ea/RT, Temperatur reaksi mempengaruhi harga konstanta laju reaksi. Kenaikan temperatur berbanding lurus dengan kenaikan laju reaksi. Pada tabel 13. nilai $\mathrm{k}$ yang diperoleh pada setiap kenaikan temperatur mengalami penurunan. Ketidakstabilan tersebut mempegaruhi laju reaksi dalam pembentukan produk. Dari data tabel 13. dibuat grafik Hubungan nilai 1/T dan $\ln \mathrm{k}$

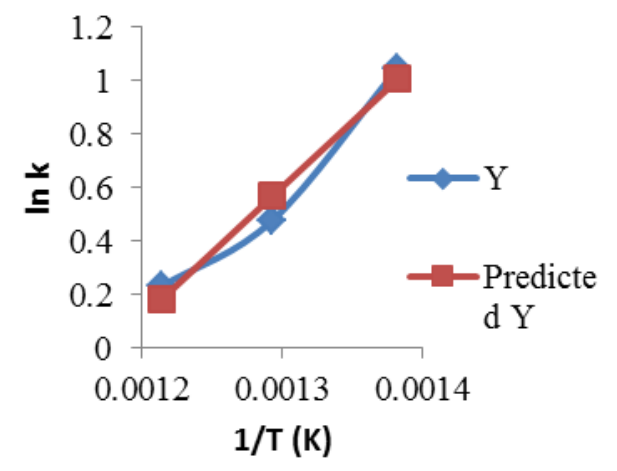

Gambar 24. Grafik Hubungan 1/T vs ln k Co-Arang $1 \%$

Dari grafik 24., nilai slope unutk perengkahan katalitik minyak jelantah menggunakan katalis CoArang $1 \%$ adalah 4888,6484 . Sehingga energi aktivasi yang didapat adalah sebesar- 40,64 kJ.

Tabel 14. Hubungan $1 / \mathrm{T}$ vs Ln K, Perengkahan Katalitik Minyak Jelantah Katalis Co-Arang $2 \%$

\begin{tabular}{cccc}
\hline $\mathrm{T}(\mathrm{K})$ & $1 / \mathrm{T}(\mathrm{K})$ & $\mathrm{k}$ & $\ln \mathrm{k}$ \\
\hline 723,15 & 0,001383 & 0,142 & $-1,948$ \\
773,15 & 0,001293 & 0,773 & $-0,256$ \\
823,15 & 0,001215 & 0,574 & $-0,553$ \\
\hline
\end{tabular}

Pada tabel 14. dapat dilihat apabila temperatur meningkat maka nilai $\mathrm{k}$ juga akan meningkat. Kenaikan temperatur berbanding lurus dengan kenaikan laju reaksi. Peningkatan ini terjadi pada temperatur $450^{\circ} \mathrm{C}$ dan $500^{\circ} \mathrm{C}$, sedangkan pada temperatur $550^{\circ} \mathrm{C}$ nilai $\mathrm{k}$ mengalami penurunan sehingga laju reaksi pun menurun. Hal ini yang menyebabkan penurunan persentase $\mathrm{CHP}$ pada temperatur $550^{\circ} \mathrm{C}$. Dari data tabel 13 . dibuat grafik Hubungan nilai 1/T dan ln $\mathrm{k}$

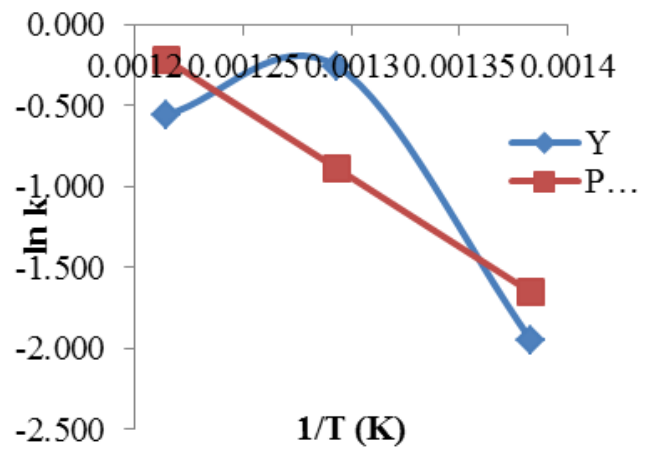

Gambar 25. Grafik Hubungan $1 / \mathrm{T}$ vs $\ln \mathrm{k}$ Co-Arang $2 \%$

Dari grafik 25 , hubungan antara $\ln \mathrm{k}$ versus $1 / \mathrm{T}$ dengan nilai $\mathrm{R}$ adalah $8,314 \mathrm{~J} / \mathrm{mol} \mathrm{K}$ nilai slope untuk perengkahan katalitik minyak jelantah menggunakan katalis Co-Arang 2\% adalah -8543,246. Sehingga diperoleh energi aktivasi sebesar 71,03 kJ.

Tabel 15. Hubungan $1 / \mathrm{T}$ vs Ln K, Perengkahan Katalitik Minyak Jelantah Katalis Co-Arang 3\%

\begin{tabular}{cccc}
\hline $\mathrm{T}(\mathrm{K})$ & $1 / \mathrm{T}(\mathrm{K})$ & $\mathrm{k}$ & $\ln \mathrm{k}$ \\
\hline 723,15 & 0,001383 & 0,005 & $-5,136$ \\
\hline
\end{tabular}




\begin{tabular}{llll}
\hline 773,15 & 0,001293 & 0,003 & $-5,577$ \\
823,15 & 0,001215 & 0,011 & $-4,493$ \\
\hline
\end{tabular}

Sesuai dengan persamaan Arhenius $\mathrm{k}=\ln \mathrm{k}_{0}$ - Ea/RT, Temperatur reaksi mempengaruhi harga konstanta laju reaksi. Kenaikan temperatur berbanding lurus dengan kenaikan laju reaksi. Pada tabel 15. nilai $\mathrm{k}$ yang diperoleh pada setiap kenaikan temperatur mengalami naik turun. Ketidakstabilan tersebut mempegaruhi laju reaksi dalam pembentukan produk. Dari data tabel 14. dibuat grafik Hubungan nilai 1/T dan $\ln \mathrm{k}$

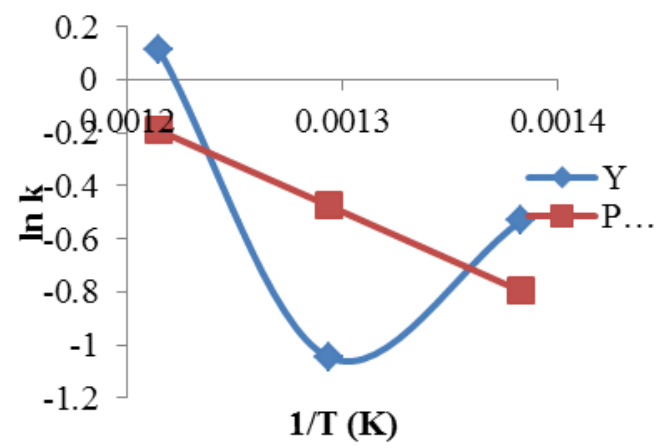

Gambar 26. Grafik Hubungan 1/T vs ln k Co-Arang 3\%

Dari tabel 4.14. dan gambar 4.21., nilai slope unutk perengkahan katalitik minyak jelantah menggunakan katalis Co-Arang 3\% adalah -3606,1445. Sehingga energi aktivasi yang didapat adalah sebesar $29,98 \mathrm{~kJ}$.

Tabel 15. Perbandingan nilai Energi Aktivasi (Ea)

\begin{tabular}{ccc}
\hline No. & Katalis & Energi Aktivasi (kJ) \\
\hline 1. & Co-Arang 1\% & $-40,64$ \\
2. & Co-Arang 2\% & 71,03 \\
3. & Co-Arang 3\% & 29,98 \\
\hline
\end{tabular}

Dari tabel 15., bahwa nilai Ea pada konsentrasi 3\% lebih rendah dibandingkan dengan konsentrasi $2 \%$. Dilihat dari konsentrasi katalis, bahwa semakin tinggi konsentrasi katalis nilai Ea semakin turun.

\section{Kesimpulan}

Dari penelitian yang telah dilakukan, dapat disimpulkan sebagai berikut :

1. Hasil pengamatan morfologi permukaan katalis Co-Arang menggunakan SEM, semakin tinggi konsentrasi katalis, semakin besar ukuran pori. Berdasarkan data EDX, Logam Co berhasil teremban ke dalam karbon aktif dengan persentase unsur Co sebesar 0,86\%, 1,99\% dan 0,11\% pada masing-masing konsenrasi logam Co. Kondisi Optimum Katalis terdapat pada katalis Co-Arang konsentrasi larutan Co $3 \%$.

2. Berdasarkan hasil perengkahan katalitik Minyak Jelantah, tidak bisa mendapatkan hubungan antara variasi konsentrasi katalis terhadap kuantitas CHP yang dihasilkan. CHP terbanyak dihasilkan pada katalis Co-Arang $1 \%$ temperatur $450^{\circ} \mathrm{C}$ yaitu sebesar $47,55 \%$. 
3. Energi aktivasi yang diperoleh tidak menunjukkan hubungan antara pengaruh waktu terhadap perengkahan katalitik. Kondisi optimum didapatkan pada perengkahan katalitik minyak jelantah variasi konsentrasi 3\% dengan energi aktivasi sebesar 29,98 kJ.

\section{Daftar Pustaka}

Abdul H, Nazarudin, and M Naswir (2017). Perengkahan Termal (Thermal Cracking) Serbuk Gergaji Kayu Bulian (Eusideroxylon Zwagery T.Et B) Untuk Menghasilkan Bahan Bakar Minyak. Jambi:Universitas Jambi

Abdulloh, A., Purkan, P., and Hardiansyah, N. (2017). Preparasi Dan Karakterisasi $\square$-Fe2o3/Zeolit Y Untuk Reaksi Perengkahan Asam Palmitat. J. Kim. Ris. 2, 69-76.

Anggoro, D.D., Hidayati, N., Buchori, L., and Mundriyastutik, Y. (2016). Effect of Co and Mo Loading by Impregnation and Ion Exchange Methods on Morphological Properties of Zeolite Y Catalyst. Bull. Chem. React. Eng. Catal. 11, 75.

Adhi W, Jayan. (2013). Perengkahan Palm Fatty Acid Distillate (PFAD) Menjadi Biofuel Menggunakan Katalis H-Zeolit Dengan Variasi Temperatur Reaksi Dan Nisbah Berat H-Zeolit/PFAD. Riau: Universitas Riau.

Alamsyah M, Ruslan K, and La I (2017). Pemurnian Minyak Jelantah Dengan Proses Adsorpsi. Univ. Muslim Indonesia. Vol 02 No.02.

Arman F, Ida Z, and Yelmida (2013). Perengkahan Katalitik Minyak Jelantah Menghasilkan Biofuel Menggunakan Katalis Femo/Zeolit. Riau: Universitas Riau.

Augustine, R.L., (1996). Heterogenous Catalysis for the Synthetic Chemistry, First Edition, Marcel DokkerInc, New York, 13-19. dalam

Bachtas, G.P., and Ida, Z. (2015). Perengkahan Katalitik Minyak Goreng Bekas Untuk Produksi Biofuel Menggunakan Katalis Ni/Zeolit. Riau: Universitas Riau.

David N, Theresia S.R. Taufik I, and , Zuhdi M (2017). Pemurnian Minyak Jelantah Menggunakan Arang Aktif Dari Sekam Padi. Tek. Kim. Fak. Tek. Univ. Tribhuwana Tunggadewi.

Deraz NM. (2018). Importance of catalyst preparation. J Ind Environ Chem. 2018;2(1):16-18

Dewi, T.K., Mahdi, M., and Novriyansyah, T. (2016). Pengaruh Rasio Reaktan Pada Impregnasi Dan Suhu Reduksi Terhadap Karakter Katalis Kobalt/Zeolit Alam Aktif. J. Tek. Kim. 22.

Erry I.R (2017). Pemanfaatan Minyak Jelantah Sebagai Biodiesel: Kajian Temperatur Dan Waktu Reaksi Transesterifikasi. Fak. Sains Dan Teknol. UIN Sunan Ampel Surabaya Vol. 12 No.3.

Fatimah, N.F., and Utami, B. (2017). Sintesis dan Analisis Spektra IR, Difraktogram XRD, SEM pada Material Katalis Berbahan Ni/zeolit Alam Teraktivasi dengan Metode Impregnasi. J. Cis-Trans 1.

Lestari, H. D. 2006. Sintesis Katalis Ni/Mo untuk Hydrotreating Coker Nafta. Tesis. Program Studi Teknik Kimia Institut Teknologi Bandung.

Lukman H.F., Adit R W., and Dr. Widayat MT. (2013). Pembuatan Katalis H-Zeolit dengan Impregnasi $\mathrm{KI} / \mathrm{KIO}_{3}$ dan Uji Kinerja Katalis Untuk Produksi Biodiesel. Jurnal Teknologi Kimia dan Industri Vol 2. UNDIP.

Hidayati, F.C. (2016). Pemurnian Minyak Goreng Bekas Pakai (Jelantah) dengan Menggunakan Arang Bonggol Jagung. JIPF J. Ilmu Pendidik. Fis. 1, 67-70.

Ida, Z. (2015). Pembuatan Biodiesel Dari Minyak Goreng Bekas Dengan Proses Catalytic Cracking. Riau: Universitas Riau.

Mahreni, M. (2010). Peluang dan Tantangan Komersialisasi Biodisel-Review. Eksergi 10, 15-26.

Mintari, D. (2015). Analisa Kadar Fe Dengan Metode Permanganometri Menggunakan Resin Penukar Ion (Ion Exchanger) Dalam Air Sungai Banjarsari (Fe Content Analysis With Permanganometry Method Using An Ion Exchanger Resin As A Filter Media In River Water Banjarsari). PhD Thesis. Undip.

Mundriyastutik, Y., Anggoro, D.D., and Hidayati, N. (2016). Preparasi Dan Karakteristik Katalis Como/Zeolit Y Dengan Metode Pertukaran Ion. Indonesia. J. Farm. 1.

Muntaha, M., Bhima, S.K.L., and Dhanardhono, T. (2013). Deteksi Psilocin Urin Pada Mencit Swiss Webster Terhadap Pemberian Jamur Psilocybe Cubensis Dosis Bertingkat. PhD Thesis. Faculty of Medicine Diponegoro University. 
Nazarudin (2000). Optimasi kondisi reaksi perengkahan katalitik Fraksi Berat Minyak Bumi dengan Katalis Cr-Zeolit dan Zeolit Alma. Yogyakarta:UGM

Nugrahaningtyas, K.D., Cahyono, E., and Widjonarko, D.M. (2016). The Paraffin Cracking Reaction With NiMo/Active Natural Zeolite Catalyst: The Effect Temperature On Catalytic Activitythe Paraffin Cracking Reaction With Nimo/Active Natural Zeolite Catalyst: The Effect Temperature On Catalytic Activity. ALCHEMY J. Penelit. Kim. 11, 111.

Nurjannah and Ifa. (2012). Studi Kinetika Perengkahan Katalitik Minyak Sawit Menghasilkan Biofuel. Makassar: Univeritas Muslim Indonesia.

Rasidi, I., Putra, A.A.B., and Suarsa, I.W. (2015). Preparasi Katalis Nikel-Arang Aktif Untuk Reaksi Hidrogenasi Asam Lemak Tidak Jenuh Dalam Minyak Kelapa.

Saputra, B., and Ida, Z. (2014). Perengkahan Katalitik Minyak Goreng Bekas Untuk Produksi Biofuel Menggunakan Katalis Cu/Zeolit. Riau: Universitas Riau.

Saputra., R Ida Z., Yelmida. (2013). "Perengkahan Katalitik Minyak Jelantah Untuk Menghasilkan Biofuel Menggunakan Katalis Ni-Mo/Zeolit.” Riau: Universitas Riau.

Sayekti, A.I.H.S.E., and Sianipar, A. (2013). Optimasi Reaksi Perengkahan Minyak Jelantah Menggunakan Katalis Zeolit/Nikel. J. Kim. Khatulistiwa 2.

Setianingsih T, Hasanah U, Darjito. (2008). Study of NaOH-activation temperatureinfluence toward character of mesoporouscarbon based on textile sludge waste. Indonesia J Chem 8:348-352.

Sembiring, Meiliata T, Sinaga T. (2003). Pengenalan dan proses pembuatan arang aktif [tesis]. Medan: Sekolah Pascasarjana,Universitas Sumatera Utara.

Shofa, Arina. (2016). "Efektivitas Jenis Katalis Pada Sintesis Terpenil Asetat Melalui Reaksi Esterifikasi $\alpha$ Pinena." PhD Thesis, Universitas Negeri Semarang.

Solihudin, Atiek R.N, Rukiah. (2015). Aktivasi Arang Sekam Padi dengan Larutan Natrium Karbonat dan Karakterisasinya. Departemen Kimia FMIPA: Universitas Padjajaran.

Sri K, Eko B.,S, and Dhian., E (2010). Aktivitas Katalis Cr/Zeolit Alam Pada Reaksi Konversi Minyak Jelantah Menjadi Bahan Bakar Cair.

Sriatun, T., and TIP, L.S. (2015). Pemanfaatan Katalis Silika Alumina Dari Bagasse Pada Pembuatan Biodiesel Dari Minyak Goreng Sisa Pakai. J. Agroindustrial Technol. 25.

Thamrin, S.P.J.T. (2013). Gasifikasi Minyak Jelantah Pada Kompor Bertekanan [Waste Cooking Oil Gasification With Pressure Stoves].

Trisunaryanti, Wega., Endang T., and Sri S. (2005). Preparasi, Modifikasi, dan Karakterisasi Katalis NiMo/Zeolit Alam dan Mo Ni/Zeolit Alam. TEKNOI 10(4): 269-282. dalam

Wijaya K, A Syoufian, and S.D. Ariantika (2014). Hydrocracking of Used Cooking Oil into Biofuel Catalyzed by Nickel-Bentonite. Asian J. Chem. 26.

Yessy M, Rahmat Ki, and Hesti W (2013). Pembuatan Arang Aktif Dari Cangkang Kelapa Sawit Dengan Aktivasi Secara Fisika, Kimia Dan Fisika-Kimia. Volume 02 No.1. 